\title{
ORNL PIE (LAMDA) Final Report on Characterization of Irradiated Grade 92 Ferritic-Martensitic Steels
}

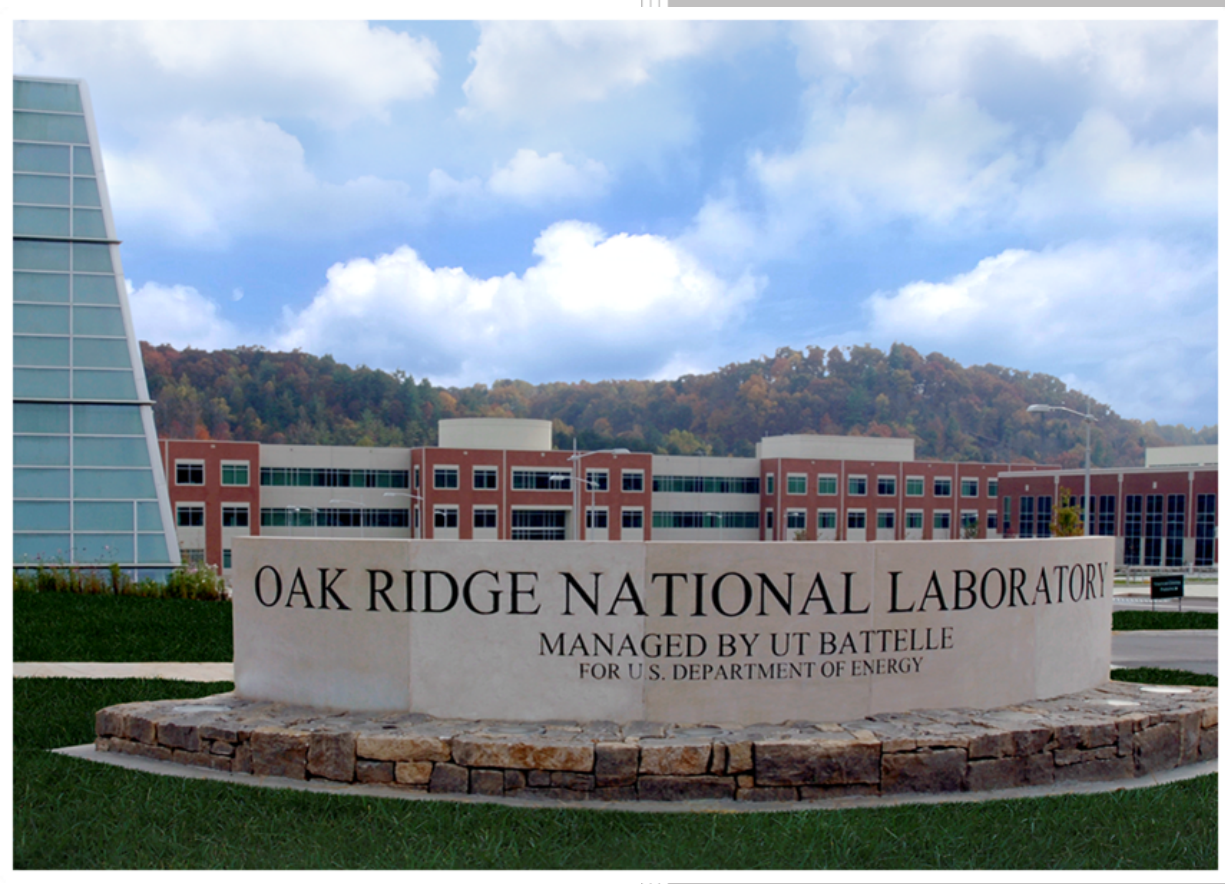

Approved for public release. Distribution is unlimited.

Weicheng Zhong Lizhen Tan

Kory Linton

Oak Ridge National Laboratory

December 2020 


\title{
DOCUMENT AVAILABILITY
}

Reports produced after January 1, 1996, are generally available free via US Department of Energy (DOE) SciTech Connect.

Website www.osti.gov

Reports produced before January 1, 1996, may be purchased by members of the public from the following source:

\author{
National Technical Information Service \\ 5285 Port Royal Road \\ Springfield, VA 22161 \\ Telephone 703-605-6000 (1-800-553-6847) \\ TDD 703-487-4639 \\ Fax 703-605-6900 \\ E-mail info@ntis.gov \\ Website http://classic.ntis.gov/
}

Reports are available to DOE employees, DOE contractors, Energy Technology Data Exchange representatives, and International Nuclear Information System representatives from the following source:

Office of Scientific and Technical Information

PO Box 62

Oak Ridge, TN 37831

Telephone 865-576-8401

Fax 865-576-5728

E-mail reports@osti.gov

Website http://www.osti.gov/contact.html

This report was prepared as an account of work sponsored by an agency of the United States Government. Neither the United States Government nor any agency thereof, nor any of their employees, makes any warranty, express or implied, or assumes any legal liability or responsibility for the accuracy, completeness, or usefulness of any information, apparatus, product, or process disclosed, or represents that its use would not infringe privately owned rights. Reference herein to any specific commercial product, process, or service by trade name, trademark, manufacturer, or otherwise, does not necessarily constitute or imply its endorsement, recommendation, or favoring by the United States Government or any agency thereof. The views and opinions of authors expressed herein do not necessarily state or reflect those of the United States Government or any agency thereof. 
ORNL/SPR-2020/1857

M3UF-21OR0210022

FY 2017 Consolidated Innovative Nuclear Research (CINR)

Nuclear Science User Facilities (NSUF)

\section{ORNL POST-IRRADIATION EXAMINATION (LAMDA) FINAL REPORT ON CHARACTERIZATION OF IRRADIATED GRADE 92 FERRITIC-MARTENSITIC STEELS}

Weicheng Zhong, Lizhen Tan, and Kory Linton

Oak Ridge National Laboratory

Date Published: December 2020

Prepared by

OAK RIDGE NATIONAL LABORATORY

Oak Ridge, TN 37831-6283

managed by

UT-BATTELLE, LLC

for the

US DEPARTMENT OF ENERGY

under contract DE-AC05-00OR22725 



\section{CONTENTS}









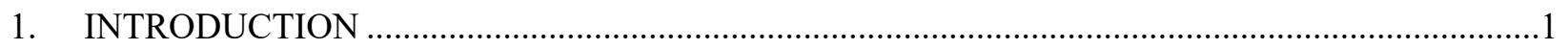

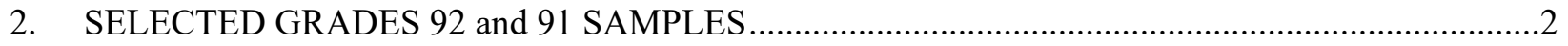

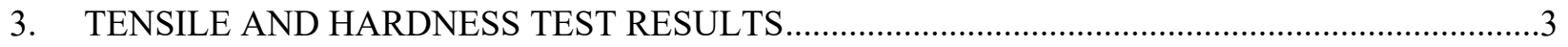

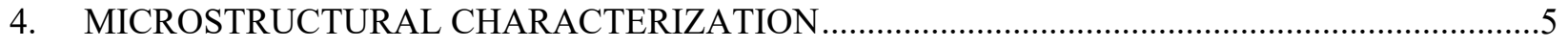

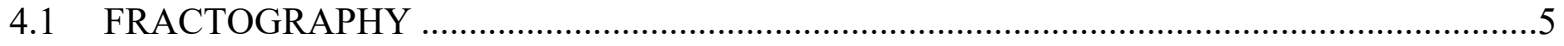

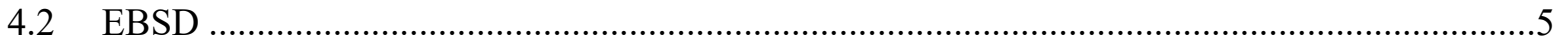

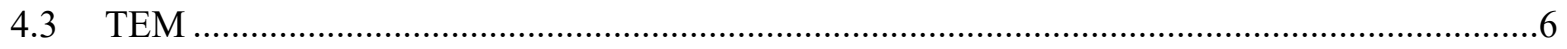

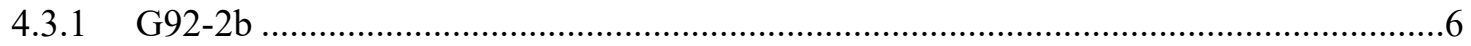

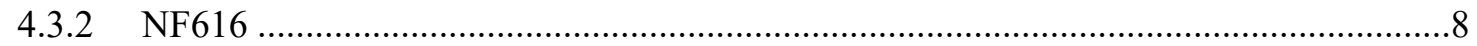

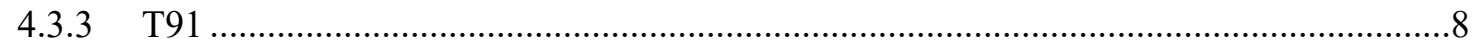

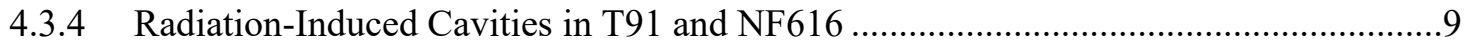

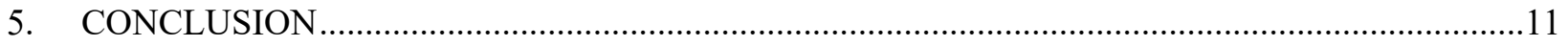

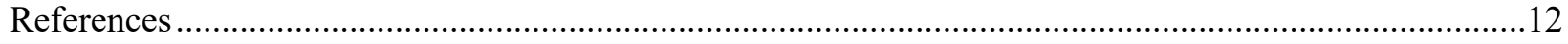




\section{LIST OF TABLES}

Table 1. Irradiation conditions of selected Grades 92 and 91 samples......

Table 2. Compositions in weight percent (wt\%) of the selected Grades 92 and 91 samples, with

$\mathrm{Fe}$ as balance.

\section{LIST OF FIGURES}

Figure 1. Tensile stress-strain curves of the selected G92-2b and NF616 samples, together with the unirradiated control sample of G92-2b.

Figure 2. Vickers hardness as a function of indentation depth of the selected G92-2b, NF616, and T91 samples, together with the unirradiated G92-2b.

Figure 3. Correlation between the changes in yield strength and Vickers hardness of the selected G92-2b, NF616, and T91, together with a 9Cr2WVTa steel.

Figure 4. Fractography example of the tensile fractured (a, d) GB03 $\left(0.5 \mathrm{dpa} / 400^{\circ} \mathrm{C}\right),(\mathrm{b}, \mathrm{e}) \mathrm{GB} 10$ $\left(0.5 \mathrm{dpa} / 683^{\circ} \mathrm{C}\right)$, and $(\mathrm{c}, \mathrm{f}) \mathrm{GB} 11\left(7.4 \mathrm{dpa} / \sim 720^{\circ} \mathrm{C}\right)$ samples.

Figure 5. EBSD example results of G92-2b $(a, b)$ archived unirradiated and $(c, d)$ GB12 (14.6 $\left.\mathrm{dpa} / \sim 720^{\circ} \mathrm{C}\right)$

Figure 6. STEM bright field images (a, c, d) and TEM dark field image (b) of the unirradiated G92-2b showing a) $\mathrm{M}_{23} \mathrm{C}_{6}$ precipitates, b) MX precipitates, c) $\mathrm{NbN}$ precipitates, and d) dislocations.

Figure 7. STEM (a, b, c, d, f) bright field images and (e) TEM dark field image of GB03 $\left(0.5 \mathrm{dpa} / 400^{\circ} \mathrm{C}\right)$ at the tensile tab section.

Figure 8. STEM (a, b, c) bright field images and (d) Nb maps near voids of GB11 $\left(7.4 \mathrm{dpa} / \sim 720^{\circ} \mathrm{C}\right)$ at the tensile tab section.

Figure 9. (a) STEM bright field image, (b) EDS V and Cr maps of the area in (a), and (c) TEM bright field image of dislocation loops in $\mathrm{D} 2\left(3 \mathrm{dpa} / 292^{\circ} \mathrm{C}\right)$ at the tensile tab section...................8

Figure 10. $(a, c)$ STEM bright field image and (b) TEM dark field image of MX precipitates of unirradiated T91 heat1.

Figure 11. STEM bright field images showing $(\mathrm{a}, \mathrm{b}) \mathrm{M}_{23} \mathrm{C}_{6}$ precipitates and (c) dislocation loops in TA04 (T91 heat 1: $\left.6.5 \mathrm{dpa} / 295^{\circ} \mathrm{C}\right)$.

Figure 12. (a,c,e) Underfocus and (b,d,f) overfocus bright field TEM images for $(\mathrm{a}, \mathrm{b})$ TA04 (T91 heat1: $\left.6.5 \mathrm{dpa} / 295^{\circ} \mathrm{C}\right),(\mathrm{c}, \mathrm{d}) \mathrm{A} 6\left(\mathrm{~T} 91\right.$ heat2: $\left.7.8 \mathrm{dpa} / 430^{\circ} \mathrm{C}\right)$, and (e,f) D6 (NF616: $\left.8.2 \mathrm{dpa} / 431^{\circ} \mathrm{C}\right)$. The exemplified cavities are marked with black arrows. 


\section{ACKNOWLEDGMENTS}

This research was sponsored by the U.S. Department of Energy (DOE), Office of Nuclear Energy (NE), the FY 2017 Consolidated Innovative Nuclear Research (CINR) Nuclear Science User Facilities (NSUF) program through the Awarded project 17-13050. This research used resources at the Low Activation Materials Design and Analysis (LAMDA) laboratory operated by the Oak Ridge National Laboratory (ORNL).

The authors are grateful to Patricia Tedder, Stephanie Curlin, Brandon Hambrick and Joshua Schmidlin of ORNL for sample reception, preparation, and hardness measurements at LAMDA. Xiang Chen and Tim Graening of ORNL are appreciated for technical review of this report. 


\section{EXECUTIVE SUMMARY}

Irradiation effects on ferritic-martensitic steel Grade 92 were investigated in this project. Samples from two heats of Grade 92, i.e., G92-2b and NF616, were selected, which were irradiated in the High Flux Isotope Reactor (HFIR) and the Advanced Test Reactor (ATR), respectively. Samples from two heats of ferriticmartensitic steel T91, irradiated in the ATR, were also selected as references for the Grade 92 samples. The selected G92-2b samples were irradiated to 0.5-14.7 displacements per atom (dpa) at two temperature regimes: $400-497^{\circ} \mathrm{C}$ and $683-720^{\circ} \mathrm{C}$. The selection of the high irradiation temperatures up to $\sim 720^{\circ} \mathrm{C}$ is to test the performance at such upper bound temperatures, which would provide insights for the upper bound applicable temperature for Grade 92. The selected NF616 and T91 samples were irradiated to 3-8.2 dpa at $292-448^{\circ} \mathrm{C}$. Except for T91 heat 2 samples in 3-mm diameter discs, all the other selected samples are of type SS-J2 miniature tensile specimens. Two Nuclear Science User Facilities (NSUF), i.e., the Irradiated Materials Examination and Testing (IMET) hot cell facility and the Low Activation Materials Design and Analysis (LAMDA) facility, were used in the Post-Irradiation Examination (PIE) activities for the selected samples, which include:

- Tensile tests at room temperature (IMET),

- Fractography of the tensile fracture surfaces (LAMDA: scanning electron microscopy and energy dispersive spectroscopy),

- Vickers hardness measurements (LAMDA),

- Microstructural characterization (LAMDA: electron backscatter diffraction, focused-ion beam, and transmission electron microscopy).

Engineering stress-strain curves of the selected samples were successfully acquired, except for one of the G92-2b sample GB11 (7.4dpa/ $\left.720^{\circ} \mathrm{C}\right)$ showing a significantly lower slope in the elastic regime. Vickers hardness measurements of the samples at three levels of loads indicated slightly decreased hardness with the increasing indentation depth/load. The changes in yield strength approximately followed a linear function with the changes in Vickers hardness, suggesting generally good tensile and hardness results.

A multiscale microstructural characterization was conducted on the selected samples. The fractography, EBSD, and TEM characterization results are exemplified using a number of the selected samples. The TEM results reveal the general grain structure and the sizes and distribution of precipitates such as $\mathrm{Cr}$-rich $\mathrm{M}_{23} \mathrm{C}_{6}$, platelet V-rich MX, and spherical NbN in the samples. Dislocation loops of both $\{100\}$ and $\{111\}$ types were present in the irradiated samples. G92-2b exhibits a few cavities after the $\sim 720^{\circ} \mathrm{C}$ irradiation. Cavities were only observed in NF616 at $431^{\circ} \mathrm{C}$ (D6: $8.2 \mathrm{dpa}$ ), which has only one third of the swelling in T91 at $430^{\circ} \mathrm{C}$ (A6: $\left.7.8 \mathrm{dpa}\right)$. In general, NF616 demonstrates better swelling resistance than T91.

Systematic data analyses are still in progress, which will be used to establish fundamental correlations between microstructures and mechanical properties. 


\section{INTRODUCTION}

Advanced alloys are desired to provide greater safety margins, design flexibility and economics compared to traditional reactor materials. Ferritic-martensitic steel Grade 92 is one of the promising alloys of interest by the current Advanced Radiation-Resistant Materials (ARRM) and Light Water Reactor Sustainability (LWRS) programs. However, systematic studies on neutron-irradiation induced changes in microstructures and mechanical properties are deficient for the alloys. The objective of this project is to conduct postirradiation examination (PIE) for the High Flux Isotope Reactor (HFIR) and the Advanced Test Reactor (ATR) irradiated Grade 92 specimens, from which correlations between microstructures and mechanical properties of the neutron-irradiated Grade 92 are expected to be developed. T91 specimens are used as reference for the Grade 92 specimens in this work.

Both irradiated and unirradiated samples from the same heat of the materials will be examined to elucidate the radiation-induced evolutions in microstructures, mechanical properties, and deformation mechanisms. Microstructural characterization of the samples will be carried out using the state-of-the-art instruments and techniques provided through the Nuclear Science User Facilities (NSUF). The obtained experimental results will then be used to establish the knowledgebase on the effects of alloy chemistry, thermomechanicalprocessing, and irradiation conditions on microstructures and mechanical properties of Grade 92.

Outcomes of this project will include a comprehensive set of data including microstructures and mechanical properties of both irradiated and unirradiated samples of the investigated steels, which will not only help understanding the essential performance of similar alloys, but more importantly to gain indispensable insights into the development of advanced alloys with superior radiation resistance. The outcomes can also serve as inputs and/or benchmarks for microstructural and mechanical property modeling of irradiated ferritic-martensitic steels. The accomplishment of this project will directly benefit the LWRS program and bring values to the Advanced Reactor Technologies and Small Modular Reactors programs. 


\section{SELECTED GRADES 92 and 91 SAMPLES}

Samples from two heats of Grade 92 and two heats of T91 were selected in this project. G92-2b is heat-1 of Grade 92, irradiated to $0.5-14.7$ dpa at 400 to $\sim 720^{\circ} \mathrm{C}$ in the HFIR at ORNL. The G92-2b is a heat of optimized Grade 92 , normalized at $1080^{\circ} \mathrm{C}$ for $1 \mathrm{~h}$, followed by hot-rolling to 0.6 "-thick plate from 1" at

$1080^{\circ} \mathrm{C}$ and water quenched, and finally tempered at $750^{\circ} \mathrm{C}$ for $2 \mathrm{~h}$ with air cooling. G92-2b exhibited improved strength and creep resistance compared with conventional Grade 92 [1]. NF616 is heat-2 of Grade 92, irradiated to 3-8.2 dpa at 292 to $431^{\circ} \mathrm{C}$ in the ATR at Idaho National Laboratory (INL). Two heats of T91 were also irradiated in ATR to $4.8-7.8 \mathrm{dpa}$ at $295-448^{\circ} \mathrm{C}$. The two heats of Grade 92 and the heat-1 of T91 have samples in type SS-J2 miniature tensile specimens with $16 \times 4 \times 0.51 \mathrm{~mm}$ overall size and $5 \times 1.2 \times 0.51$ $\mathrm{mm}$ for the gauge section. The heat-2 T91 samples are in 3-mm diameter discs. The selected samples and their irradiation conditions are listed in Table 1, together with the heat compositions in

Table 2 .

Table 1. Irradiation conditions of selected Grades 92 and 91 samples.

\begin{tabular}{|c|c|c|c|c|c|c|}
\hline Reactor & Specimen type & Alloy & Sample ID & Temperature $\left({ }^{\circ} \mathrm{C}\right)$ & Dose (dpa) & Flux (dpa/s) \\
\hline \multirow{6}{*}{ HFIR } & \multirow{10}{*}{ SS-J2 } & \multirow{6}{*}{$\begin{array}{l}\text { G92-2b } \\
\text { (heat1) }\end{array}$} & GB03 & 400 & 0.5 & $5.8 \times 10^{-7}$ \\
\hline & & & GB04 & $\sim 490$ & 7.4 & $6.8 \times 10^{-7}$ \\
\hline & & & GB05 & 497 & 14.7 & $7.5 \times 10^{-7}$ \\
\hline & & & GB10 & 683 & 0.5 & $8.3 \times 10^{-7}$ \\
\hline & & & GB11 & $\sim 720$ & 7.4 & $6.9 \times 10^{-7}$ \\
\hline & & & GB12 & $\sim 720$ & 14.6 & $8.4 \times 10^{-7}$ \\
\hline \multirow{6}{*}{ ATR } & & \multirow{3}{*}{$\begin{array}{l}\text { NF616 } \\
\text { (heat2) }\end{array}$} & $\mathrm{D} 2$ & 292 & 3 & $5.3 \times 10^{-8}$ \\
\hline & & & $\mathrm{D} 4$ & 359 & 5.9 & $1.1 \times 10^{-7}$ \\
\hline & & & D6 & 431 & 8.2 & $1.5 \times 10^{-7}$ \\
\hline & & T91 (heat1) & TA04 & 295 & 6.5 & $3.5 \times 10^{-7}$ \\
\hline & \multirow{2}{*}{ 3-mm disc } & \multirow{2}{*}{ T91 (heat2) } & $\mathrm{A} 4$ & 448 & 4.8 & $8.5 \times 10^{-8}$ \\
\hline & & & A6 & 430 & 7.8 & $1.4 \times 10^{-7}$ \\
\hline
\end{tabular}

Table 2. Compositions in weight percent (wt\%) of the selected Grades 92 and 91 samples, with Fe as balance.

\begin{tabular}{|c|c|c|c|c|c|c|c|c|c|c|c|c|c|c|c|}
\hline Alloy & $\mathrm{Cr}$ & $\mathrm{Ni}$ & $\mathrm{Mn}$ & $\mathrm{Si}$ & $\mathrm{Ti}$ & $\mathrm{V}$ & $\mathrm{W}$ & $\mathrm{Mo}$ & $\mathrm{Nb}$ & $\mathrm{Cu}$ & $\mathrm{C}$ & $\mathrm{N}$ & $\mathrm{P}$ & $\mathrm{S}$ & $\mathrm{Al}$ \\
\hline G92-2b (heat1) & 8.9 & 0.10 & 0.47 & 0.14 & & 0.23 & 1.9 & 0.43 & 0.11 & & 0.087 & 0.045 & & & \\
\hline NF616 (heat2) [2] & 8.8 & 0.17 & 0.45 & 0.10 & & 0.19 & 1.87 & 0.47 & 0.06 & & 0.109 & 0.047 & 0.012 & 0.003 & \\
\hline T91 (heat1) [3] & 9.2 & 0.18 & 0.46 & 0.24 & 0.002 & 0.24 & 0.013 & 0.96 & 0.06 & 0.087 & 0.052 & 0.057 & 0.016 & 0.001 & 0.009 \\
\hline T91 (heat2) [2] & 8.4 & 0.21 & 0.45 & 0.28 & & 0.22 & & 0.90 & 0.08 & 0.17 & 0.10 & 0.048 & 0.009 & 0.003 & 0.022 \\
\hline
\end{tabular}




\section{TENSILE AND HARDNESS TEST RESULTS}

The SS-J2 miniature specimens of the G92-2b and NF616 were tensile tested at room temperature using an Instron ElectroPlus E1000 test system located in Cell-2 in the Irradiated Materials Examination and Testing (IMET) hot cell facility at ORNL. The specimens were shoulder loaded to provide goo alignment in tension. The crosshead speed during testing was kept constant at $0.012 \mathrm{in} / \mathrm{min}$, corresponding to a nominal strain rate of $1 \times 10^{-3} \mathrm{~s}^{-1}$. The load versus crosshead displacement responses of the specimens were measured throughout the tests so the stress strain curves could be calculated, as shown in Figure 1. The HFIRirradiated G92-2b samples are presented in solid curves, together with the unirradiated control condition of G92-2b shown as a black curve, while the ATR-irradiated NF616 samples are displayed as dashed curves. The GB11 stress strain curve is likely not reliable. Unexpected flaws might have occurred during the test of GB11, e.g., slip during the loading period in the elastic regime. All the other stress strain curves provide meaningful results. The T91 heat 1 sample TA04 was tensile tested at Los Alamos National Laboratory and reported in Ref. [3].

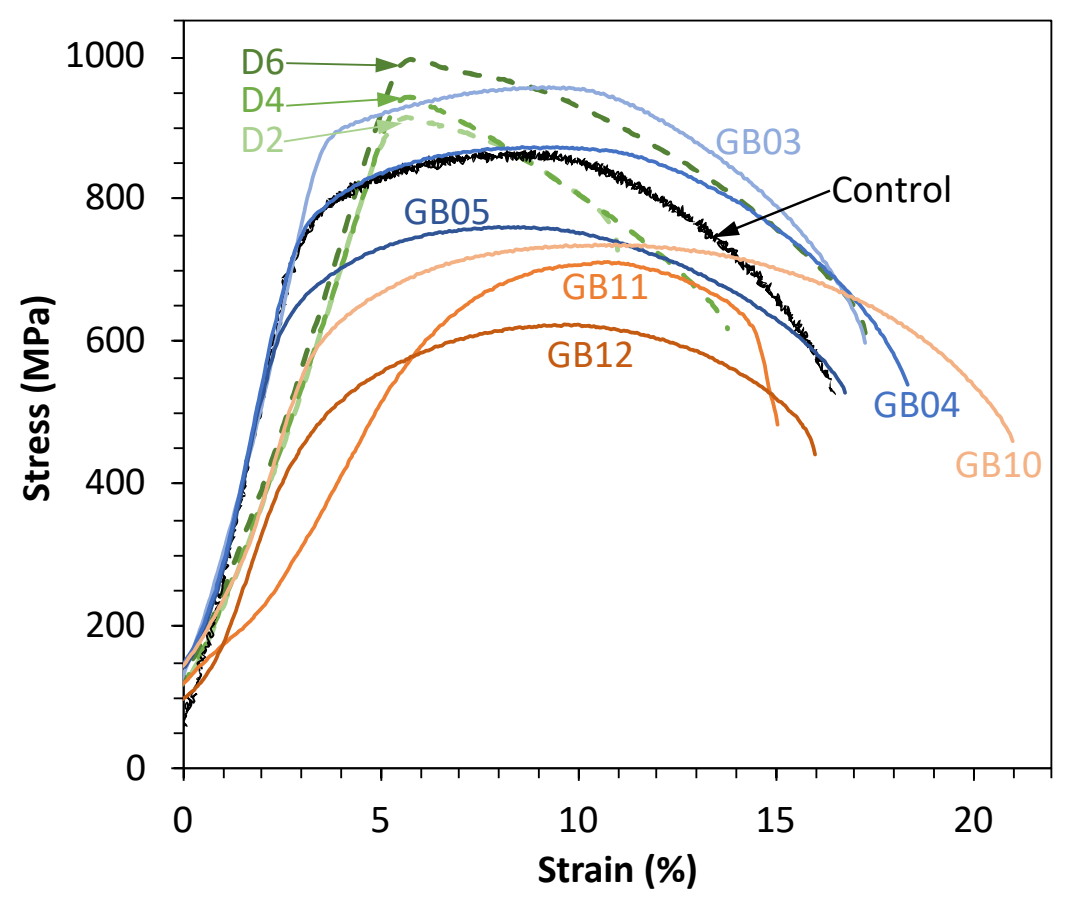

Figure 1. Tensile stress-strain curves of the selected G92-2b and NF616 samples, together with the unirradiated control sample of G92-2b.

One of the tensile tested broken halves of the SS-J2 specimens and the 3-mm discs were mechanically polished to a mirror finish for Vickers hardness measurements. Vickers hardness measurements were conducted at three levels of loads of $0.1,0.5$, and $1 \mathrm{kgf}$ with five measurements per load. Figure 2 shows the average Vickers hardness with standard deviation of the control and irradiated G92-2b, NF616, and T91 samples as a function of indentation depth induced by the three levels of loads. The samples generally show reduced hardness with the greater indentation depth/load. 


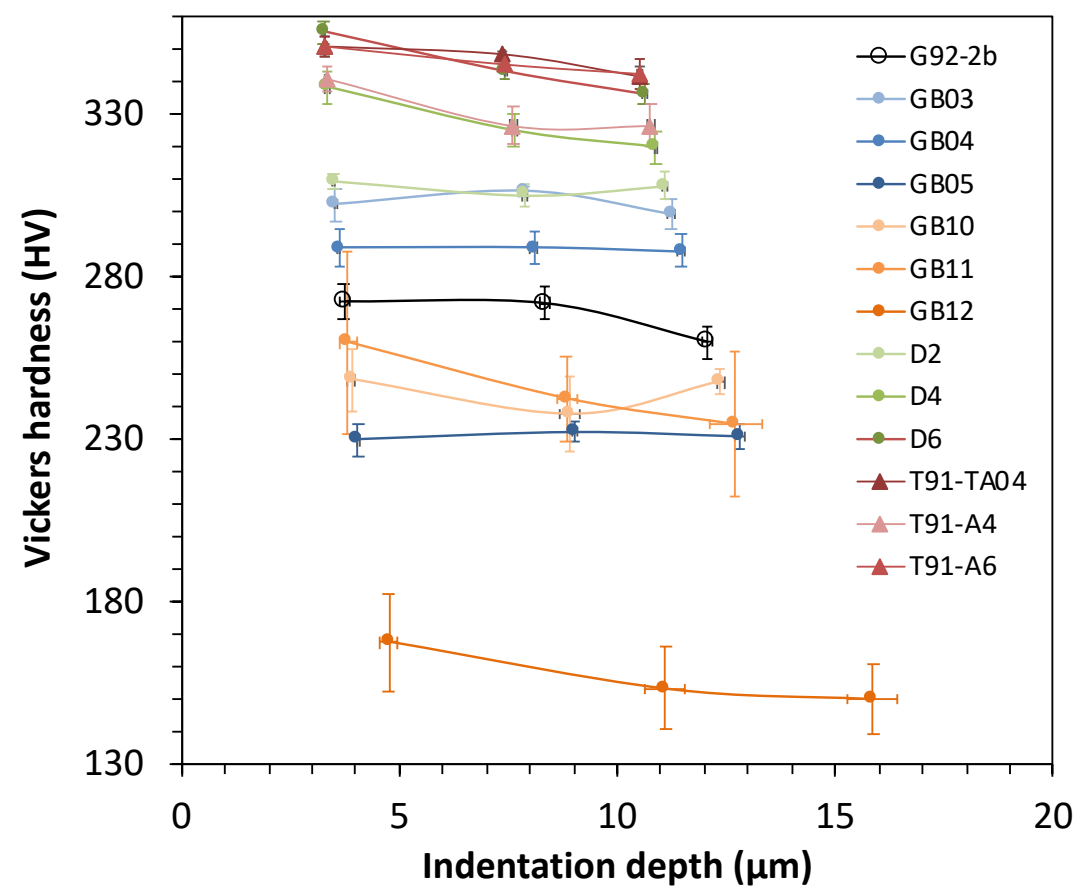

Figure 2. Vickers hardness as a function of indentation depth of the selected G92-2b, NF616, and T91 samples, together with the unirradiated G92-2b.

Figure 3 summarizes the changes in yield strength as a function of changes in Vickers hardness for the selected G92-2b, NF616, and T91 samples, together with a few data from a 9Cr2WVTa steel. The results fit well with a linear function of $\Delta \sigma_{\mathrm{ys}}(\mathrm{MPa}) \approx 3.28 \Delta H_{\mathrm{V}}(\mathrm{HV} 1)$.

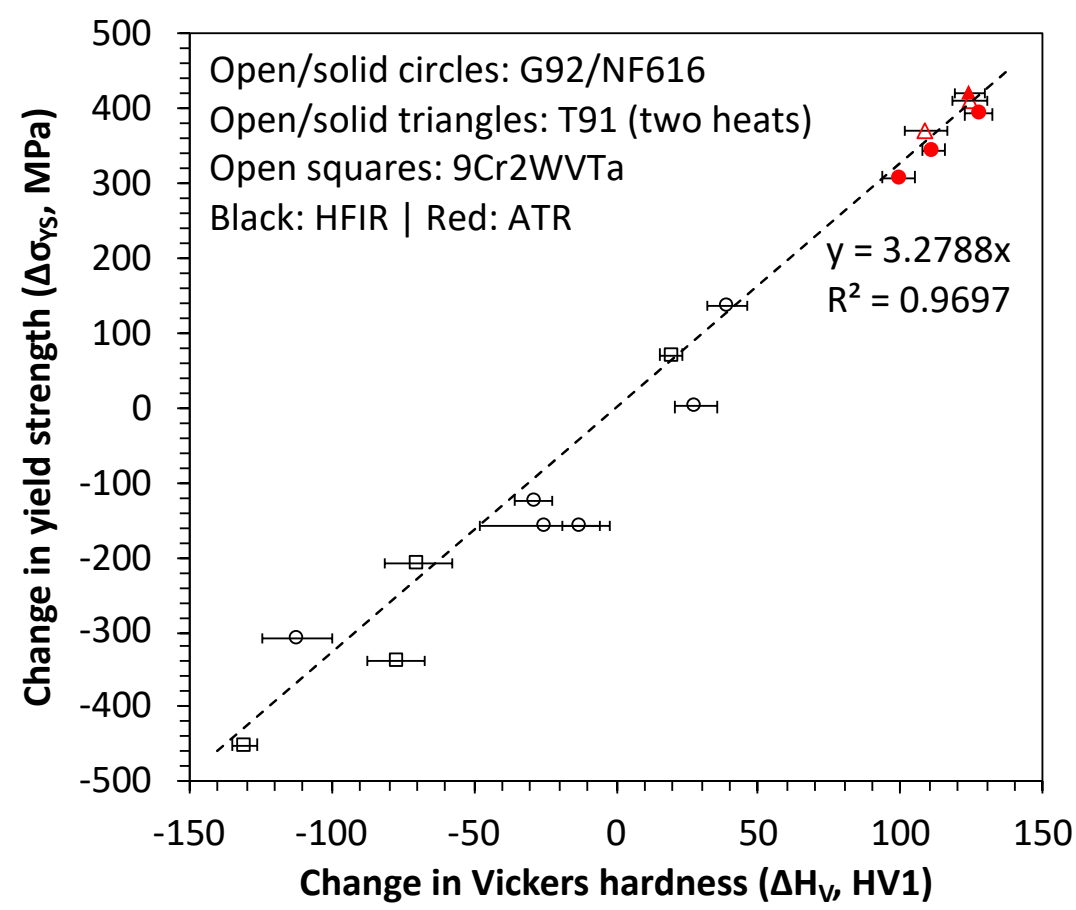

Figure 3. Correlation between the changes in yield strength and Vickers hardness of the selected G92-2b, NF616, and T91, together with a 9Cr2WVTa steel. 


\section{MICROSTRUCTURAL CHARACTERIZATION}

A multiscale microstructural characterization was conducted during the PIE in LAMDA after the tensile tests. Fractography was performed on the fracture surface of the tensile-tested samples using scanning electron microscopy (SEM: TESCAN MIRA3 GMH) and energy dispersive x-ray spectroscopy (EDS: Bruker Quantax) prior to polishing the samples to a mirror finish. Microstructures of the samples were characterized using electron backscatter diffraction (EBSD: Oxford Instruments Symmetry) on the polished samples and transmission electron microscopy (TEM: JEOL JEM2100F and FEI Talos F200X) on electron transparent thin lamellae prepared using focused-ion beam (FIB: FEI Versa 3D Dual Beam and Quanta 3D 200i Dual Beam) for lift-outs from the polished samples.

\subsection{FRACTOGRAPHY}

Fractography analysis was conducted on the tensile fractured samples of G92-2b and NF616. Figure 4 shows an example for the fractography of the tensile fractured G92-2b samples GB03, GB10, and GB11. GB03 ( $0.5 \mathrm{dpa})$ and GB10 (0.5 dpa) that have a similar low dose showed more evident necking than the higher dose sample GB11 (7.4 dpa). GB11 shows large dimple size, on the order of a few micrometers. Nbcontaining particles, identified by EDS, were observed inside some of the dimples, and these particles have a size of a few hundred nanometers. Clustering of $\mathrm{Nb}$-containing particles is present inside dimples in GB11, as arrow-pointed in the inset of Figure 4f.
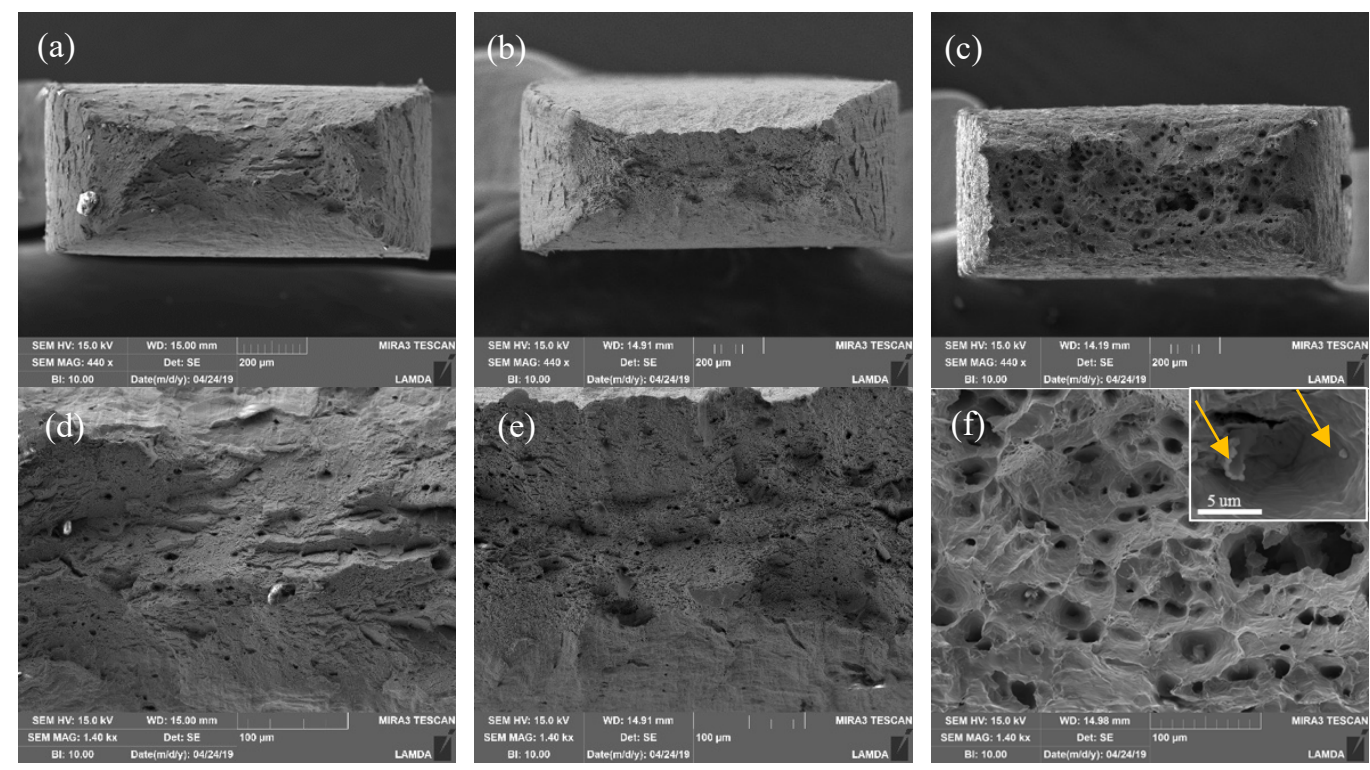

Figure 4. Fractography example of the tensile fractured (a, d) GB03 $\left(0.5 \mathrm{dpa} / 400^{\circ} \mathrm{C}\right),(\mathrm{b}, \mathrm{e}) \mathrm{GB10}\left(0.5 \mathrm{dpa} / 683^{\circ} \mathrm{C}\right)$, and $(\mathrm{c}, \mathrm{f}) \mathrm{GB} 11\left(7.4 \mathrm{dpa} / \sim 20^{\circ} \mathrm{C}\right)$ samples.

\subsection{EBSD}

EBSD was performed on selected samples. Figure 5 shows an example for the EBSD results of the archived unirradiated G92-2b and the irradiated GB12 $\left(14.6 \mathrm{dpa}\right.$ at $\left.\sim 720^{\circ} \mathrm{C}\right)$. The EBSD results are in inverse pole figure for the two conditions/samples at two levels of magnification. The unirradiated G92-2b showed

typical martensitic morphology, as shown in Figure 5a and Figure 5b. In contrast, GB12 lose the fine lath martensitic structure after irradiation at $\sim 720^{\circ} \mathrm{C}$, which showed coarse approximately equiaxed grain 
morphology, as shown in Figure 5c. The high magnification image of GB12 in Figure 5d shows that the larger grain is generally consisted of small domains with low angle boundaries.

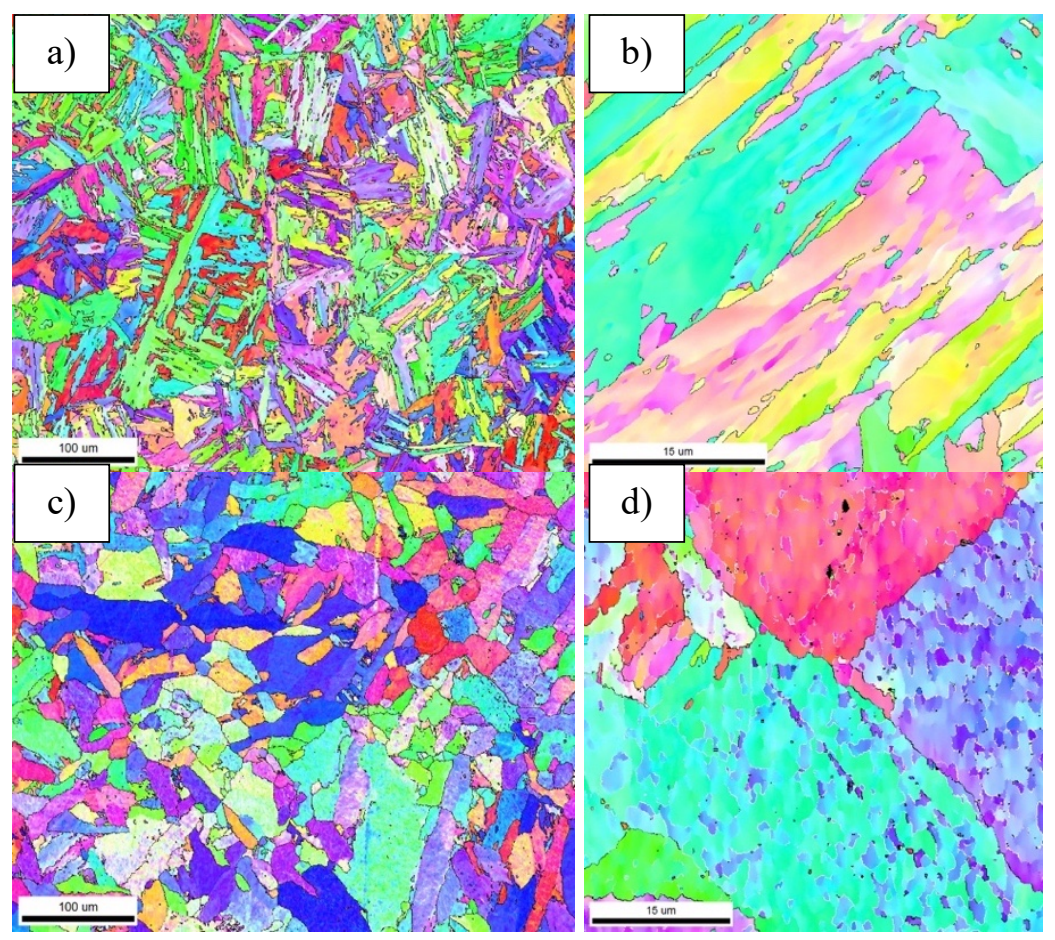

Figure 5. EBSD example results of G92-2b (a, b) archived unirradiated and (c, d) GB12 (14.6 dpa/ 720 $\left.{ }^{\circ} \mathrm{C}\right)$.

\subsection{TEM}

Detailed TEM characterization was performed on the selected G92-2b, NF616, and T91 samples. Examples of the TEM results are shown in the following subsections for different steels.

\subsubsection{G92-2b}

Figure 6 shows the typical microstructure of the unirradiated G92-2b, illustrating a lath structure with width ranging from $100 \mathrm{~nm}$ to $400 \mathrm{~nm}$. Precipitates $\mathrm{M}_{23} \mathrm{C}_{6}(\mathrm{M}=\mathrm{Cr}$ primarily) mainly decorated the boundaries, as shown in Figure 6a. The size of $\mathrm{M}_{23} \mathrm{C}_{6}$ precipitates was estimated using $\sqrt{L W}$, where $L$ and $W$ are the length and the width of $\mathrm{M}_{23} \mathrm{C}_{6}$ precipitates. The average size of $\mathrm{M}_{23} \mathrm{C}_{6}$ precipitates was $69 \pm 25 \mathrm{~nm}$. Figure $6 \mathrm{~b}$ shows $\mathrm{V}$-rich MX phase platelet precipitates in the matrix. The image was taken under the two-beam condition of $\mathrm{g}_{200}$ near [001] zone. In addition, $\mathrm{Nb}(\mathrm{C}, \mathrm{N})$ precipitates are present inside grains, as pointed in Figure $6 \mathrm{c}$. The $\mathrm{Nb}(\mathrm{C}, \mathrm{N})$ precipitates have a spherical morphology with a size of about $25 \mathrm{~nm}$. Figure $6 \mathrm{~d}$ shows the image of dislocation lines under the [001] zone axis. An average density of $6.7 \times 10^{14} \mathrm{~m}^{-2}$ for the dislocation lines was estimated from multiple images. 



Figure 6. STEM bright field images (a, c, d) and TEM dark field image (b) of the unirradiated G92-2b showing a) $\mathrm{M}_{23} \mathrm{C}_{6}$ precipitates, b) $\mathrm{MX}$ precipitates, c) $\mathrm{NbN}$ precipitates, and d) dislocations.

Figure 7 shows the microstructure of $\operatorname{GB} 03\left(0.5 \mathrm{dpa} / 400^{\circ} \mathrm{C}\right)$ at the tensile tab section, where is assumed to be stress free. Lath structure seems coarser, with some grains having the width of over $1 \mu \mathrm{m}$ as shown in Figure $7 \mathrm{a} . \mathrm{M}_{23} \mathrm{C}_{6}$ precipitates decorate boundaries, which have an elongated shape along boundaries as shown in Figure $7 \mathrm{~b}$. Spherical $\mathrm{Nb}(\mathrm{C}, \mathrm{N})$ precipitates are distributed within grains, which have sizes from 20 $\mathrm{nm}$ to $30 \mathrm{~nm}$ as shown in Figure $7 \mathrm{c}$ with a core-shell structure. The fast Fourier transform (FFT) of the core indicates the [011] zone of $\mathrm{Nb}(\mathrm{C}, \mathrm{N})$ precipitate in the inset of Figure 7c, with a lattice parameter of 4.457 $\pm 0.086 \AA$. A cluster of precipitates at a grain boundary was also observed, as shown in Figure $7 \mathrm{~d}$, which include $\mathrm{M}_{23} \mathrm{C}_{6}$ precipitates (pointed by the black arrows), a spherical Nb-rich precipitate (pointed by the orange arrow), and a V-rich precipitate (pointed by the red arrow). Figure 7e shows the dark field image, taken under the two-beam condition of $\mathrm{g}_{200}$ near [011] zone, of MX platelet precipitates, similar to the MX in the unirradiated sample in Figure $6 \mathrm{~b}$. Figure $7 \mathrm{f}$ shows the dislocation lines, taken under the [001] zone, having a density of $5.9 \times 10^{14} \mathrm{~m}^{-2}$, comparable to the unirradiated sample.


Figure 7. STEM (a, b, c, d, f) bright field images and (e) TEM dark field image of GB03 $\left(0.5 \mathrm{dpa} / 400^{\circ} \mathrm{C}\right)$ at the tensile tab section. 
Figure 8 shows the microstructure of GB11 $\left(7.4 \mathrm{dpa} / \sim 720^{\circ} \mathrm{C}\right)$ at the tensile tab section. Similar to the EBSD result in Figure 5c, equiaxed grain structure is pronounced in the tab section of GB11, as shown in the Figure 8a. A few thick dislocation walls are evident in the top left grain of Figure 8a, which might be the pre-existing packet and block boundaries. Figure $8 \mathrm{~b}$ shows the dislocation lines under the [001] zone with a dislocation density of $7.7 \times 10^{13} \mathrm{~m}^{-2}$. Voids were observed near dislocation networks, as shown in Figure $8 \mathrm{c}$. $\mathrm{Nb}$ shells are observed around voids, as shown in the $\mathrm{Nb}$-maps in Figure 8d.
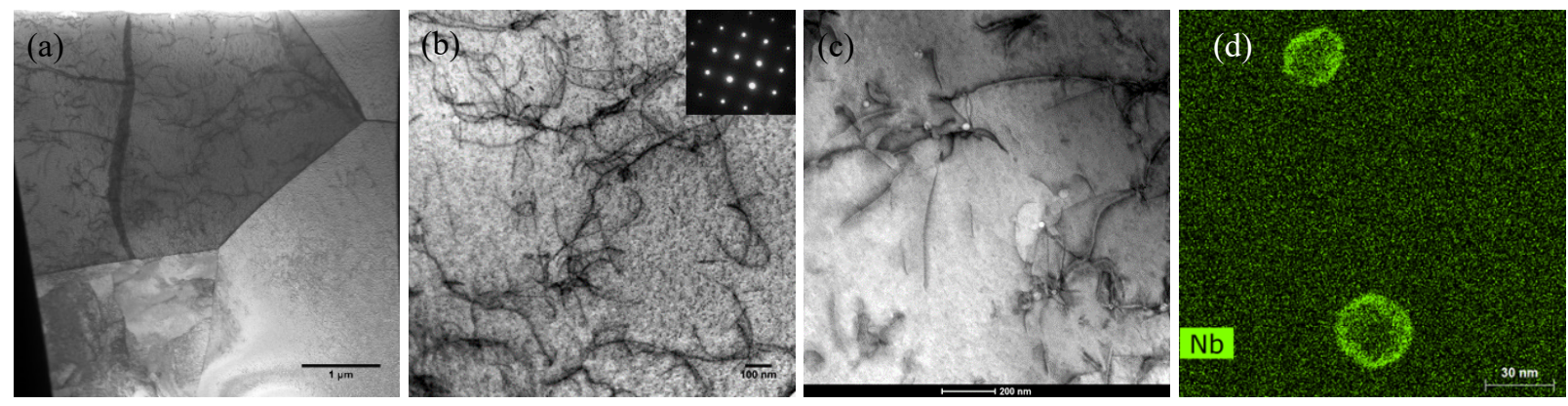

Figure 8. STEM (a, b, c) bright field images and (d) Nb maps near voids of $\mathrm{GB11}\left(7.4 \mathrm{dpa} / \sim 720^{\circ} \mathrm{C}\right)$ at the tensile tab section.

\subsubsection{NF616}

Figure 9 shows the microstructure of D2 $\left(3 \mathrm{dpa} / 292^{\circ} \mathrm{C}\right)$ at the tensile tab section. The fine structures such as laths and refined subgrains are evident in Figure 9a. The same area EDS mapping of $\mathrm{V}$ and $\mathrm{Cr}$ is shown in Figure 9b, indicating that the prior-austenite grain boundary and some lath/subgrain boundaries are primarily decorated by $\mathrm{Cr}$-rich $\mathrm{M}_{23} \mathrm{C}_{6}$, together with some $\mathrm{V}$-rich $\mathrm{MX}$ precipitates. Dislocation loops, as exemplified by the marked arrows in Figure $9 \mathrm{c}$, were imaged under the two-beam condition $g_{110}$ near [-110] zone.
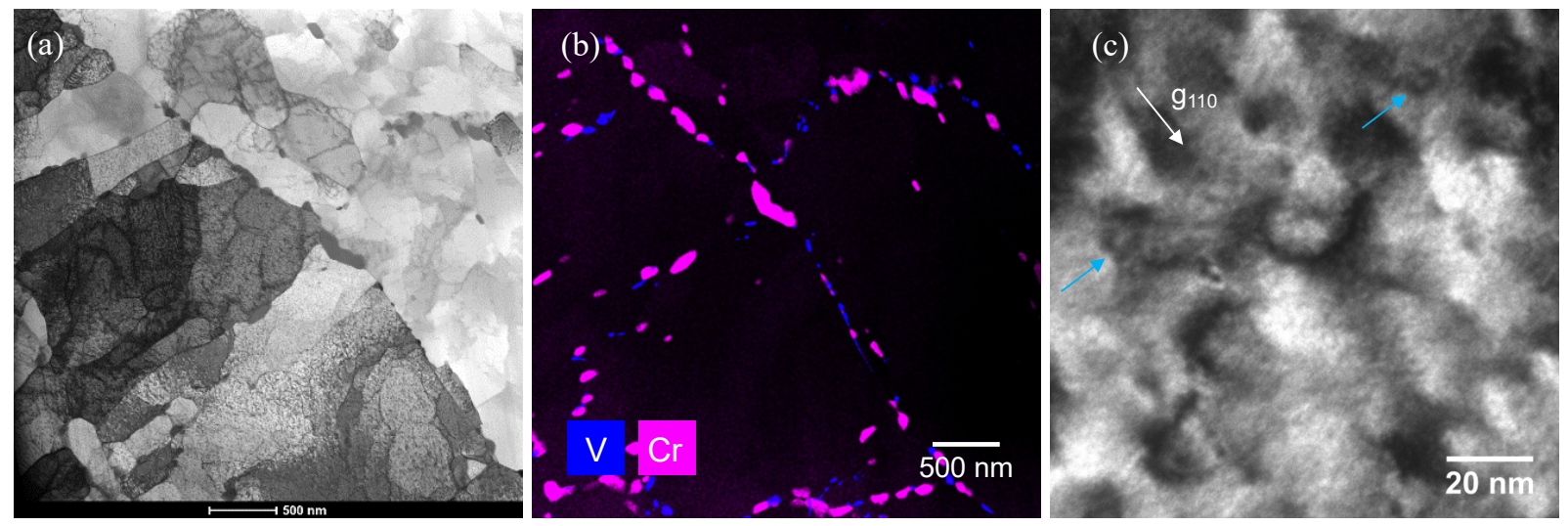

Figure 9. (a) STEM bright field image, (b) EDS V and $\mathrm{Cr}$ maps of the area in (a), and (c) TEM bright field image of dislocation loops in $\mathrm{D} 2\left(3 \mathrm{dpa} / 292^{\circ} \mathrm{C}\right)$ at the tensile tab section.

\subsubsection{T91}

Microstructure of the unirradiated T91 heat1 is shown in Figure 10. The overall image shows $\mathrm{M}_{23} \mathrm{C}_{6}$ precipitates at grain boundaries, as pointed in Figure 10a. The average size of the $\mathrm{M}_{23} \mathrm{C}_{6}$ precipitates is 68 
$\pm 22 \mathrm{~nm}$. Nanoscale MX precipitates are present, as shown in the dark field image in Figure 10b. The image was taken under the two-beam condition $\mathrm{g}_{200}$ near [001] zone, as the diffraction pattern shown in the inset of Figure 10b. Dislocation network in STEM bright field image of Figure 10c was taken under [001] zone, with a density of $6 \times 10^{14} \mathrm{~m}^{-2}$.
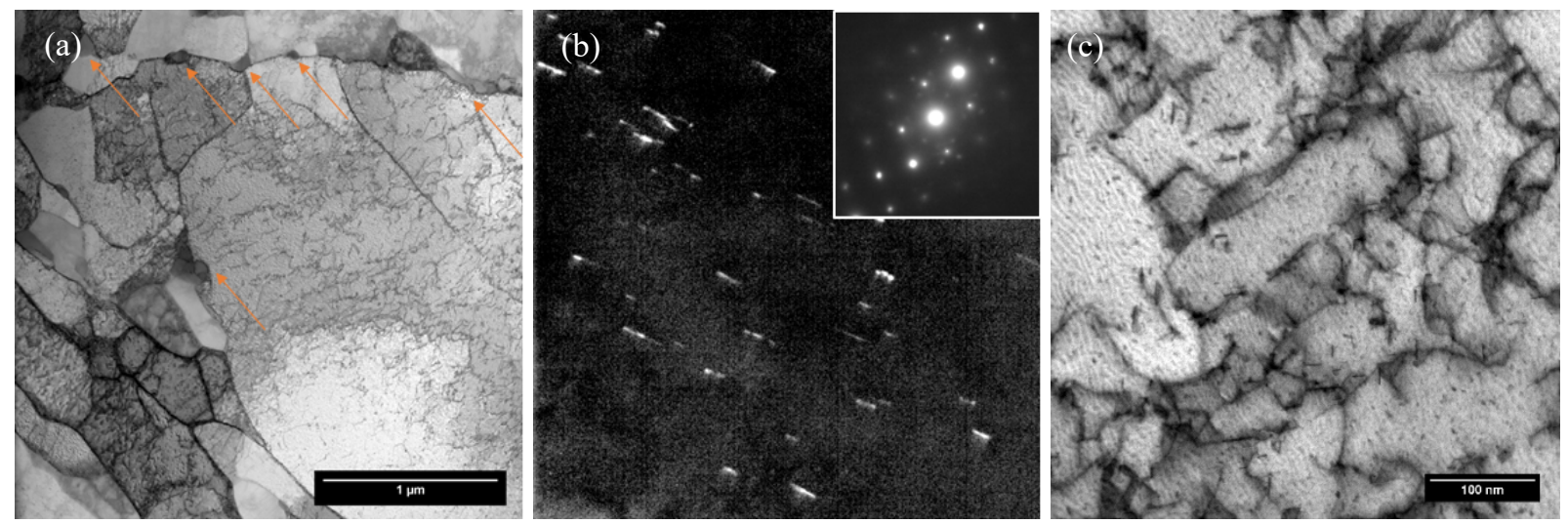

Figure 10. (a,c) STEM bright field image and (b) TEM dark field image of MX precipitates of unirradiated T91 heat1.

The microstructure of the TA04 (T91 heat1: $\left.6.5 \mathrm{dpa} / 295^{\circ} \mathrm{C}\right)$ is shown in Figure 11. Figure 11a shows the STEM bright field image demonstrating the $\mathrm{M}_{23} \mathrm{C}_{6}$ precipitates. The average size of $\mathrm{M}_{23} \mathrm{C}_{6}$ precipitates was estimated to be $101 \pm 40 \mathrm{~nm}$, which is $48.5 \%$ increase in size compared to the unirradiated T91 heat $1 . \mathrm{M}_{23} \mathrm{C}_{6}$ precipitates are accumulated at grain boundaries. Figure $11 \mathrm{~b}$ shows the region as labeled in the dashed box in Figure 11a. Smaller grains are observed within the regions where $\mathrm{M}_{23} \mathrm{C}_{6}$ precipitates are accumulated, indicating the pinning effect of $\mathrm{M}_{23} \mathrm{C}_{6}$ precipitates on the grain growth. Dislocation loops formed in the irradiation environment, as shown in the STEM bright field image under [100] zone in Figure 11c. Both $\{111\}$ and $\{100\}$ type dislocations were observed.
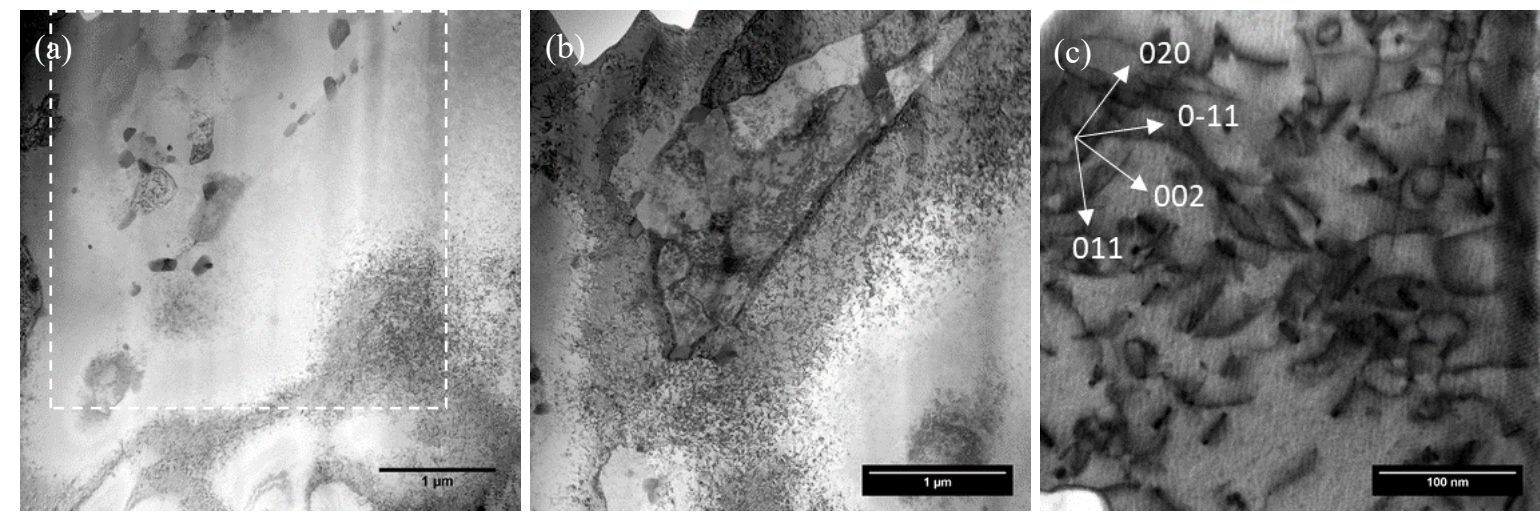

Figure 11. STEM bright field images showing (a, b) $M_{23} C_{6}$ precipitates and (c) dislocation loops in TA04 (T91 heat1: $\left.6.5 \mathrm{dpa} / 295^{\circ} \mathrm{C}\right)$.

\subsubsection{Radiation-Induced Cavities in T91 and NF616}

Figure 12 shows the underfocus and overfocus images of cavities in TA04 (T91 heat1: $6.5 \mathrm{dpa} / 295^{\circ} \mathrm{C}$ ), A6 (T91 heat2: $7.8 \mathrm{dpa} / 430^{\circ} \mathrm{C}$ ), and D6 (NF616: $\left.8.2 \mathrm{dpa} / 431^{\circ} \mathrm{C}\right)$. D6 (NF616) shows smaller cavities with higher density than A6 (T91 heat2) irradiated to a similar dose at about an identical temperature. The 
characterized swelling of D6 (NF616) is about one third of that in A6 (T91 heat2), indicating a better swelling resistant of NF616 than T91. Although TA04 (T91 heat1) was irradiated at a lower temperature $\left(295^{\circ} \mathrm{C}\right)$ to a slightly lower dose $(6.5 \mathrm{dpa})$, it exhibited larger cavities and swelling than A6 (T91 heat2). In contrast, no cavities were observed in NF616 irradiated at lower temperatures $\left(292^{\circ} \mathrm{C}\right.$ and $359^{\circ} \mathrm{C}$ for D2 and $\mathrm{D} 4$, respectively).
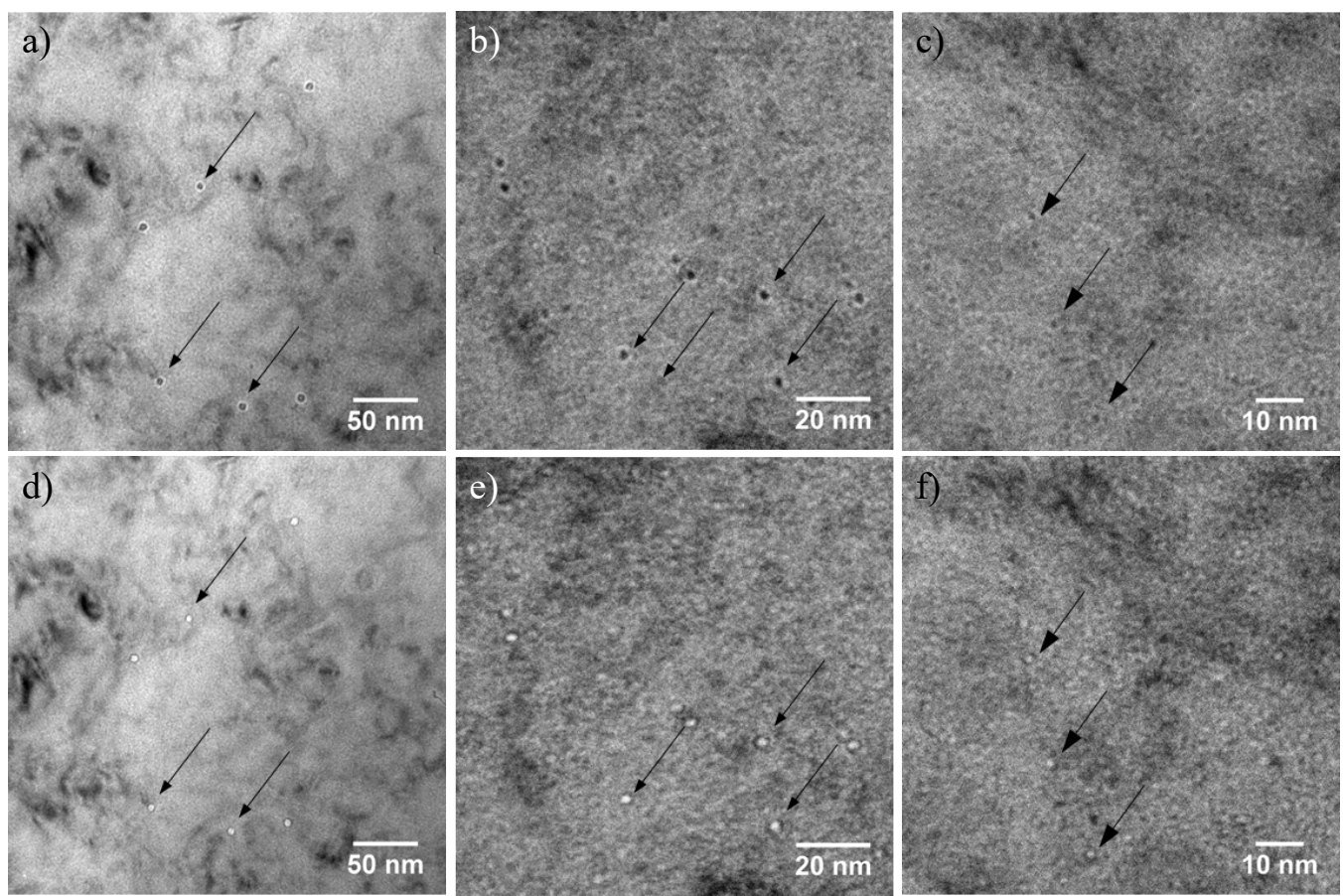

Figure 12. (a,c,e) Underfocus and (b,d,f) overfocus bright field TEM images for (a,b) TA04 (T91 heat1: 6.5dpa $\left./ 295^{\circ} \mathrm{C}\right),(\mathrm{c}, \mathrm{d}) \mathrm{A6}\left(\mathrm{T} 91\right.$ heat2: $\left.7.8 \mathrm{dpa} / 430^{\circ} \mathrm{C}\right)$, and (e,f) D6 (NF616: 8.2dpa/431 $\left.{ }^{\circ} \mathrm{C}\right)$. The exemplified cavities are marked with black arrows. 


\section{CONCLUSION}

Samples of Grade 92 steels G92-2b and NF616, together with reference samples from two heats of T91, were selected for comparison in this project. G92-2b samples were irradiated to $0.5-14.7 \mathrm{dpa}$ at $400-720^{\circ} \mathrm{C}$ in the HFIR while NF616 and the two heats of T91 samples were irradiated to $3-8.2$ dpa at $292-448^{\circ} \mathrm{C}$ in the ATR. Except for T91 heat2 samples in 3-mm diameter discs, all the other steel samples are of type SS-J2 miniature tensile specimens. PIE activities for the selected samples included tensile test at room temperature using the IMET hot cell facility and fractography (SEM/EDS), Vickers hardness measurements, and microstructural characterization (SEM/EBSD, FIB, TEM/EDS) using the LAMDA facility.

Engineering stress-strain curves of the selected samples were successfully acquired, except for one of the G92-2b sample GB11. Vickers hardness measurements of the samples at three levels of loads indicated slightly decreased hardness with the increasing indentation depth/load. The changes in yield strength approximately followed a linear function with the changes in Vickers hardness, suggesting generally good results of the tensile tests and hardness measurements.

A multiscale microstructural characterization was conducted on the selected samples. Fractography results used GB03 $\left(0.5 \mathrm{dpa} / 400^{\circ} \mathrm{C}\right)$, GB10 $\left(0.5 \mathrm{dpa} / 683^{\circ} \mathrm{C}\right)$, and GB11 $\left(7.4 \mathrm{dpa} / \sim 720^{\circ} \mathrm{C}\right)$ as examples. EBSD results used the unirradiated G92-2b and GB12 $\left(14.6 \mathrm{dpa} / \sim 720^{\circ} \mathrm{C}\right)$ as examples to show the recovery of subgrain structures and replaced by an equiaxed grain structure after the irradiation at $\sim 720^{\circ} \mathrm{C}$. TEM characterization used unirradiated G92-2b, GB03 $\left(0.5 \mathrm{dpa} / 400^{\circ} \mathrm{C}\right)$, GB11 $\left(7.4 \mathrm{dpa} / \sim 720^{\circ} \mathrm{C}\right)$, and NF616-D2 $\left(3 \mathrm{dpa} / 292^{\circ} \mathrm{C}\right)$, together with T91 heat 1 unirradiated and TA04 $\left(6.5 \mathrm{dpa} / 295^{\circ} \mathrm{C}\right)$, as examples. The TEM results revealed the general grain structure and the sizes and distribution of precipitates such as Cr-rich $\mathrm{M}_{23} \mathrm{C}_{6}$, platelet Vrich MX, spherical $\mathrm{NbN}$ in the samples. Dislocation loops of both $\{100\}$ and $\{111\}$ types were present in the irradiated samples. G92-2b exhibited a few cavities at the $\sim 720^{\circ} \mathrm{C}$ irradiation. Cavities were only observed in NF616 at $431^{\circ} \mathrm{C}$ (D6: $8.2 \mathrm{dpa}$ ), which has swelling only one third of that in T91 at $430^{\circ} \mathrm{C}$ (A6: $7.8 \mathrm{dpa})$. In general, NF616 demonstrates better swelling resistant than T91. 


\section{REFERENCES}

[1] L. Tan, P. J. Maziasz and T. L. Sham, "Report on the optimization and testing results of advanced ferritic/martensitic alloys. ORNL/TM-2012/288," 2012.

[2] H.J. MacLean, K. Sridharan, T.A. Hyde, "Irradiation Test Plan for the ATR National Scientific User Facility - University of Wisconsin Pilot Project," Idaho National Laboratory (INL), INL/EXT-0915627, June 2008.

[3] S. A. Maloy, T. A. Saleh, O. Anderoglu, T. J. Romero, G. R. Odette, T. Yamamoto, S. Li, J. I. Cole and R. Fielding, "Characterization and comparative analysis of the tensile properties of five tempered martensitic steels and an oxide dispersion strengthened ferritic alloy irradiated at $\approx 295^{\circ} \mathrm{C}$ to $\approx 6.5$ dpa," Journal of Nuclear Materials, vol. 468, pp. 232-239, 2016. 